\title{
Criminal Liability for Crimes Against Humanity as a Problem of International Law
}

\section{Introduction}

Our prehistoric approach now leads us to consider in detail the successive definitions of the concept of crimes against humanity in international law, as well as the other basic texts of international law which directly contribute to its understanding. The process of legal conceptualization of crimes against humanity, as it is presented to the contemporary observer, spans less than a century. Begun as such during the Second World War, it first gave rise to a relatively short paragraph leading to the consequent text of the Rome Statute of the 1998. The definition of 'crimes against humanity' is codified in Article 7 of the Rome Statute of the International Criminal Court (ICC). "The notion encompasses crimes such as murder, extermination, rape, persecution and all other inhumane acts of a similar character (willfully causing great suffering, or serious injury to body or to mental or physical health), committed as part of a widespread or systematic attack directed against any civilian population, with knowledge of the attack." Crimes against humanity have both a colloquial and a legal existence. ${ }^{1}$ Usually, the term is employed to condemn any number of atrocities that violate international human rights. As a legal construct, crimes against humanity encompass a constellation of acts made criminal under international law when they are committed within the context of a widespread and systematic attack against a civilian population. ${ }^{2}$ In the domain of international criminal law, crimes against humanity are an increasingly useful component of any international

1 V. C. Bassiouni, Crimes Against Humanity in International Criminal Law, The Hague-LondonBoston 1999; A. Cassese, Crimes Against Humanity: Comments on some Problematical Aspects in: The International Legal System in Quest of Equity and Universality. Liber Amicorum Georges Abi-Saab, eds. L. Boisson De Chazournes, V. Gowlland-Debbas, The Hague-London-Boston 2001, pp. 429-447.

2 The concept of crimes against humanity is closely linked to the evolution of international criminal justice. The road traveled since the beginning of the twentieth century in this area with different Courts and legal decisions to formalize and clarify certain terms such as crime against 
prosecutor's toolbox, because they can be charged in connection with acts of violence that do not implicate other international criminal prohibitions, such as the prohibitions against war crimes (which require a nexus to an armed conflict) and genocide (which protects only certain human groups and requires proof of a specific intent to destroy such a group). ${ }^{3}$ Although the concept of crimes against humanity has deep roots, crimes against humanity were first adjudicated - albeit with some controversy - in the criminal proceedings following the World War II period. ${ }^{4}$ The central challenge to defining crimes against humanity under international criminal law since then has been to come up with a formulation of the offense that reconciles the principle of sovereignty - which envisions an exclusive territorial domain in which states are free from outside scrutinywith the idea that international law can, and indeed should, regulate certain acts committed entirely within the borders of a single state. Because many enumerated crimes against humanity are also crimes under domestic law (e.g., murder, assault, and rape), it was necessary to define crimes against humanity in a way that did not elevate every domestic crime to the status of an international crime, subject to international jurisdiction. Over the years, legal drafters have experimented with various elements in an effort to arrive at a workable penal definition. The definitional confusion plaguing the crime over its life span generated a considerable amount of legal scholarship. It was not until the UN Security Council promulgated the statutes of the two ad hoc international criminal tribunals - the International Criminal Tribunal for the Former Yugoslavia and the International Criminal Tribunal for Rwanda - that a modern definition of the crime

humanity or genocide is important; v. M. Guzman, The road from Rome: the Developing Law of Crimes Against Humanity, "Human Rights Quarterly" 2000, vol. 22, p. 335.

$3 \mathrm{~V}$. V. Dadrian, The Historical and Legal Interconnections Between the Armenian Genocide and the Jewish Holocaust: From Impunity to Retributive Justice, „Yale Journal of International Law” 1998, no. 23, pp. 503-559; S. Garibian, Crimes against humanity and international legality in legal theory after Nuremberg, "Journal of Genocide Research" 2007, no. 1: pp. 93-111; V. S. C. Res. 1674, 8, U.N. Doc. S/RES/1674 (Apr. 28, 2006). V. also S.C. Res. 1820, U.N. Doc. S/RES/1820 (June 19, 2008) (reaffirming "the resolve expressed in the 2005 World Summit Outcome Document to eliminate all forms of violence against women and girls, including by ending impunity); noting that rape and other forms of sexual violence can constitute a war crime, a crime against bumanity, or a constitutive act with respect to genocide, calling upon "Member States to comply with their obligations for prosecuting persons responsible for such acts, and stressing the importance of ending impunity for such acts; S.C. Res. 1261,4, U.N. Doc. S/RES/1261 (Aug. 25, 1999) (The responsibility of all States [is] to bring an end to impunity and their obligation to prosecute those responsible for grave breaches of the Geneva Conventions...).

4 The concept is transposed into national law only after its original adoption in international law. We can count three contexts of reception of the concept by the national legislations: after the Second War following the adoption of one of the specialized international conventions (the Convention on the Prevention and Punishment of the Crime of Genocide and the International Convention on the Suppression and Punishment of the Crime of Apartheid) or following the creation of the International Criminal Court, $V$. E. Fronza, Le crime contre l'humanité, Paris 2009, p. 51. 
emerged. ${ }^{5}$ These definitions were further refined by the case law of the two tribunals and their progeny, such as the Special Court for Sierra Leone. All these doctrinal developments were codified, with some additional modifications, in a consensus definition in Article 7 of the Statute of the International Criminal Court (ICC). It is now clear that the offense constitutes three essential elements: 1 . the existence of a widespread or systematic attack against a civilian population and 2. the intentional commission of an enumerated act (such as an act of murder or torture) 3. by an individual with knowledge that his or her act would contribute to the larger attack. A renewed effort is now afootto promulgate a multilateral treaty devoted to crimes against humanity based on the ICC definition and these central elements. Through this dynamic process of codification and interpretation, many - but not all-definitional issues left open in the postwar period have finally been resolved. Although their origins were somewhat shaky, crimes against humanity now have a firm place in the canon of international criminal law.

\section{The Issue of Crime Against Humanity in International Criminal Law}

The use of the term "crimes against humanity" can be traced back to late eighteenth and early nineteenth century. ${ }^{6}$ The term was used in the context of slavery and the slave trade, and to describe atrocities associated with European colonialism in Africa and elsewhere such as, for example, the atrocities committed by Leopold II of Belgium in the Congo Free State. The term appears to have been applied for the first time formally at the international level in 1915 by the Allied governments when issuing a declaration

5 The creation of two new ad hoc International Criminal Tribunals, respectively for the former Yugoslavia (ICTY: May 25, 1993) and Rwanda (ICTR: November 8, 1994) was the occasion for the United Nations Security Council to redefine the notion of crime against humanity.

6 This formulation stems from the work of the first International Peace Conference, held in The Hague from 18 May to 29 July 1899. However, the authors cite the Martens clause more often in reference to the preamble to the Convention concerning the laws and the customs of war on earth adopted on October 18, 1907, during the Second International Peace Conference, held at The Hague from June 15 to October 18, 1907. In general, it is found expressed - more or less partially - in several texts relating to international humanitarian law. Here are some notable occurrences: in the four Geneva Conventions of 12August 1949, in Resolution XXIII on the respect of human rights in armed conflict adopted by the International Human Rights Conference of Tehran on 12 May 1968, in the Protocols to the Geneva Conventions of 1949 adopted on 8 June 1977 (V. Article 1, clause 2 of Protocol I and Preamble to Protocol II) or in the Convention on the Prohibition or Restriction of the Use of Certain Conventional Weapons which may be considered as producing excessive traumatic or indiscriminate effects adopted on 10 October 1980 in the context of the UN Conference of the same name. 
condemning the mass killing of Armenians in the Ottoman Empire. ${ }^{7}$ At the beginning of the renaissance of international criminal law in the 1990s, the law on crimes against humanity was in a fragile state. The International Criminal Tribunal for the former Yugoslavia (ICTY) decisively contributed to the consolidation of customary international law on crimes against humanity and paved the way for its first comprehensive codification in Article 7 of the Statute of the International Criminal Court (ICC). At the same time, the ICTY in its early decisions already showed a certain inclination to broaden the scope of the application of the crime by downgrading its contextual requirement. More recently, this tendency culminated in the complete abandonment of the policy requirement. While this 'progressive' facet of the ICTY's jurisprudence largely took the form of obiter dicta, the situation in the Republic of Kenya confronted the ICC with the need to 'get serious' about the present state of the law. ${ }^{8}$ This has led to a controversy in Pre-Trial Chamber II about the concept of organization in Article 7(2) (a) of the Statute. ${ }^{9}$ While the majority essentially follows the path of the more recent case law of the ICTY, the ICTR, and the Special Tribunal for Sierra Leone and supports a liberal interpretation, Judge Kaul prefers to confine the term to state-like organizations and generally calls for caution against too hasty an expansion of the realm of international criminal law stricto sensu. This comment agrees with the main thrust of the Dissenting Opinion and hopes that it will provoke a thorough debate.

This does not exclude a development of the law. Such a development would, however, constitute a very important step. The jurisdiction of the International Military Tribunal at Nuremberg was limited to aggression, war crimes committed in international armed conflicts, and, if committed inexecution or connection with one of the preceding crimes, crimes against humanity. ${ }^{10}$ By clearly linking all these crimes with a breach of international peace in the strict meaning of the term, the first generation of international

7 V. S. Garibian, Génocide arménien et conceptualisation du crime contre l'bumanité. De l'intervention pour cause d'humanité à l'intervention pour violation des lois de l'bumanité, "Revue d'histoire de la Shoah" 2003, pp. 177-178: pp. 274-294; v. also V. Dadrian, The Historical and Legal Interconnections Between the Armenian Genocide and the Jewish Holocaust: From Impunity to Retributive Justice, "Yale Journal of International Law", 23: 1998, pp. 503-559.

8 G. Mettraux, Crimes Against Humanity in the Jurisprudence of the International Criminal Tribunals for the Former Yugoslavia and for Rwanda, "Harvard International Law Journal", 2002, pp. 237-316.

9 The judicial debate which has been the subject of the foregoing reflections is not only a textbook example of the challenges involved in the interpretation of the Statute. Its outcome is of paramount importance for the future development of the law on crimes against humanity. V. C. BassiouniI, Crimes Against Humanity: The Need for a Specialized Convention, "Columbia Journal of Transnational Law" 1994, pp. 457-494, A. Cassese, Crimes against Humanity, in: The Rome Statute of the International Criminal Court: A Commentary, eds. A. Cassese, P. Gaeta, J. R. W. D. Jones, Oxford 2002, pp. 353-378.

10 D. Kastrup, From Nuremberg to Rome and Beyond: the Fight Against Genocide, War Crimes and Crimes Against Humanity (Dedicated to the United Nations High Commission for Human Rights: 
criminal law reflected, despite its revolutionary recognition of criminality directly under international law, the traditional, almost entirely state-centred, configuration of the international legal order. In the by-now historic decision of the ICTY's Appeals Chamber in Tadic case, a decisive step towards a second generation of international criminal law was taken. The Chamber reached the conclusion that criminality directly under international law had extended to armed conflicts not of an international character. This legal determination was complemented by a second and equally significant finding that crimes against humanity under customary international law may be committed in peacetime. The crystallization of customary war crimes committed in conflicts not of an international character, and the emergence of crimes against humanity by making them an autonomous crime, moved the protective scope of international criminal law beyond interstate incidents to also cover certain forms of intrastate strife. It now encompasses situations where a government and/or state-like organization (typically in the form of armed opposition forces) spread terror among the people under its power. The situation in most African states raises the question whether international criminal law is to make a third generational step and would move into the area of national and transnational conflicts between states and destructive private organizations of all kinds. This would mean that the law's protective thrust, which was hitherto confined to situations of war and internal strife, would extend to protect states and their populations from internal or external threats emanating from private persons. Such an important move should not be initiated by the international judiciary but should rather be supported by a solid amount of state practice.

To a large extent, uncertainty abounds, to start with the precise contours of the concept "international law crimes" itself. Even if one day one were to reach a consensus on conceptually clear legal definitions and obligations, the major obstacle might well turn out to be the States' being often politically unwilling to implement in practice their duty to prosecute international law crimes. In order to overcome this, attention needs to be turned to assess the factors which induce States to prosecute international law crimes. Even more fundamentally, no effort should be spared to look for appropriate fora in which to challenge a State's decision not to prosecute despite an international obligation to do so. As previously indicated, it remains to be seen in the coming years what influence the Rome Statute will exercise upon this practice.

While, as previously mentioned, the ICC has been given jurisdiction over both genocide and crimes against humanity, this leaves unanswered the question whether States are under an international legal obligation to prosecute genocide and crimes against humanity, committed in or outside their territory and by their or by foreign nationals respectively. In respect of genocide, the answer to the question raised is less controversial than in respect of crimes against humanity. Indeed, the 1948 Convention on the

Genocide, War Crimes and Crimes against Humanity), "Fordham International Law Journal" 1999, vol. 23, pp. 404- 414. 
Prevention and Punishment of the Crime of Genocide confirms, in its Article I, that "genocide, whether committed in time of peace or in time of war, is a crime under international law which they (the Contracting Parties) undertake to prevent and to punish". This undertaking to punish individuals having committed genocide is repeated in Article IV. Pursuant to Article V, all Contracting Parties have the obligation to enact, inter alia, criminal legislation applicable to perpetrators of genocide.

The existence of a duty to prosecute crimes against humanity is a different case: indeed, apart from their definition in the International Law Commission's "Principles of International Law recognized in the Charter of the Nürnberg Tribunal and in the Judgment of the Tribunal" (1950), no international treaty defined the concept until recently. Even though a substantial amount of authors seem to agree there exists a duty to prosecute crimes against humanity for the State on whose territory the crimes were committed, it is uncertain to what extent actual State practice confirms the doctrinal point of view that, as international crimes, they should be sanctioned with universal jurisdiction. Indeed, many States which did provide for domestic legislation over crimes against humanity committed abroad included requirements in terms of links with the State prosecuting the crimes, thus remaining below true universal jurisdiction. In this respect too, it is to be hoped that the coming years, benefiting from a definition agreed upon in the Rome Statute, will provide further guidance of the extent to which States consider they are bound by a customary international law duty to prosecute crimes against humanity committed abroad.

\section{Conclusion}

In the light of this analysis, crime against humanity is a concept transcending both the international legal order and the national legal order. As much to say that this notion upsets legal thought of common law. Its definition is precise but leaves many questions as to the extent of its content, and as to the very identity of the concept or its specificity. Its magnitude is universal but has many restrictions. This paradox reveals the idea of transcendence of the notion of crime against humanity. The prohibition of crimes against humanity is based on a much broader concept of justice than our current legal system can offer. Moreover, as a norm of jus cogens, the prohibition of crimes against humanity stands out as an imperative, as a supreme rule at the top of the hierarchy of norms. The municipal law of States is only a legal fact for international law, Article 33 of the Statute of the International Criminal Court perfectly illustrates this indifference to municipal law since the mere order of the law does not exempt commission of crimes against humanity. This universal and transcendental aspect of the prohibition of crimes against humanity over the classical legal systems, however, knows the limits of its application. Indeed, if the universal vocation is widely accepted in the standard-setting, the repressive justice system is much less inclined 
to such an enlargement. The rule against the commission of crimes against humanity is dualistic and opposes its vocation to its use. The current trend in the written evolution of the notion is towards enlargement. We can ask to what point the notion of crime against humanity can be extended or if this notion really aims to expand. Crime against humanity is not an autonomous concept, it depends on the legal system that surrounds it. Its content is not intended to be universal since it would encroach on the object of other national or international criminal standards.

Delimitating crime against humanity seems easier since the creation of the Rome status. However, this delimitation only concerns the extent of its commission but not the extent of its existence. The delimitation given in the definition of a crime against humanity of the Statute of the International Criminal Court is not a stable and unambiguous delimitation, since the essence of the concept does not lie in a conventional definition but in custom and there is no real definition of crime against humanity. The perimeter of the crime against humanity cannot be drawn from the conception that crime against humanity is a norm of natural law. Because on the basis of this conception, the crime against humanity will always be the object of a quest for truth which will not allow it to take a particular status within the international legal order. Setting up the perimeter of the crime against humanity therefore requires a positivist and realistic conception oflaw. However, today, the place of crime against humanity in the international legal order is still subject to too many questions that do not allow the limits to be established.

\section{Literature}

Ascensio, H., Lambert-Abselgawad, E. Sorel, J.-M. ed., Les juridictions pénales internationalisées, Cambodge, Kosovo, Sierra Leone, Timor Leste 2006.

Bassiouni, C., Crimes Against Humanity in International Criminal Law, The HagueLondon- Boston 1999.

BassiouniI, C., Crimes Against Humanity: The Need for a Specialized Convention, "Columbia Journal of Transnational Law”, 1994.

Cassese, A., Crimes against Humanity, in: The Rome Statute of the International Criminal Court: A Commentary, eds. Cassese A., Gaeta P., Jones J. R., Oxford 2002.

Cassese, A., Crimes Against Humanity: Comments on some Problematical Aspects, in: Boisson De Chazournes, L., Gowlland-Debbas, V. eds., The International Legal System in Quest of Equity and Universality. Liber Amicorum Georges Abi-Saab, The HagueLondon-Boston, 2001.

Dadrian, V., The Historical and Legal Interconnections Between the Armenian Genocide and the Jewish Holocaust: From Impunity to Retributive Justice, "Yale Journal of International Law"1998, no. 23.

Fronza E., Le crime contre l'humanité, Paris 2009. 
84 | Adam Mickiewicz University Law Review

Garibian S., Le crime contre l'bumanité au regard des principes fondateurs de l'Etat moderne. Naissance et consécration d'un concept de Droit, Genève 2007.

Garibian, S., Crimes against humanity and international legality in legal theory after Nuremberg, "Journal of Genocide Research" 2007, no. 1.

Garibian, S., Génocide arménien et conceptualisation du crime contre l'humanité. De l'intervention pour cause d'humanité à l'intervention pour violation des lois de l'bumanité, "Revue d'histoire de la Shoah" 2003.

Guzman M. The road from Rome: the developing law of crimes against humanity, "Human Rights Quarterly"2000, vol. 22.

Kastrup D., From Nuremberg to Rome and beyond: the fight against genocide, war crimes and crimes against humanity (Dedicated to the United Nations High Commission for Human Rights: Genocide, War Crimes and Crimes against Humanity), "Fordham International Law Journal” 1999, vol. 23.

Mettraux G., Crimes Against Humanity in the Jurisprudence of the International Criminal Tribunals for the Former Yugoslavia and for Rwanda, "Harvard International Law Journal”, 2002.

\section{SUMMARY}

\section{Criminal Liability for Crimes Against Humanity as a Problem of International Law}

The article sets out the nature, the history and the general structure of the crime against humanity and provides a comprehensive analytical commentary of the elements of such crimes as a problem of international law. The contextual element determines that crimes against humanity involve either large-scale violence in relation to the number of victims or its extension over a broad geographic area (widespread), or a methodical type of violence (systematic). This excludes random, accidental or isolated acts of violence. In addition, Article 7(2) (a) of the Rome Statute determines that crimes against humanity must be committed in furtherance of a State or organizational policy to commit an attack. The plan or policy does not need to be explicitly stipulated or formally adopted and can, therefore, be inferred from the totality of the circumstances. In contrast with genocide, crimes against humanity do not need to target a specific group. Instead, the victim of the attack can be any civilian population, regardless of its affiliation or identity.

Keywords: International law, crimes, humanity, liability, genocide, war crimes.

Boubacar Sidi Diallo, Adam Mickiewicz University Poznań, Faculty of Law and Administration, Al. Niepodległości 53, 61-714 Poznań, Republic of Poland, e-mail: diallo@amu.edu.pl. 